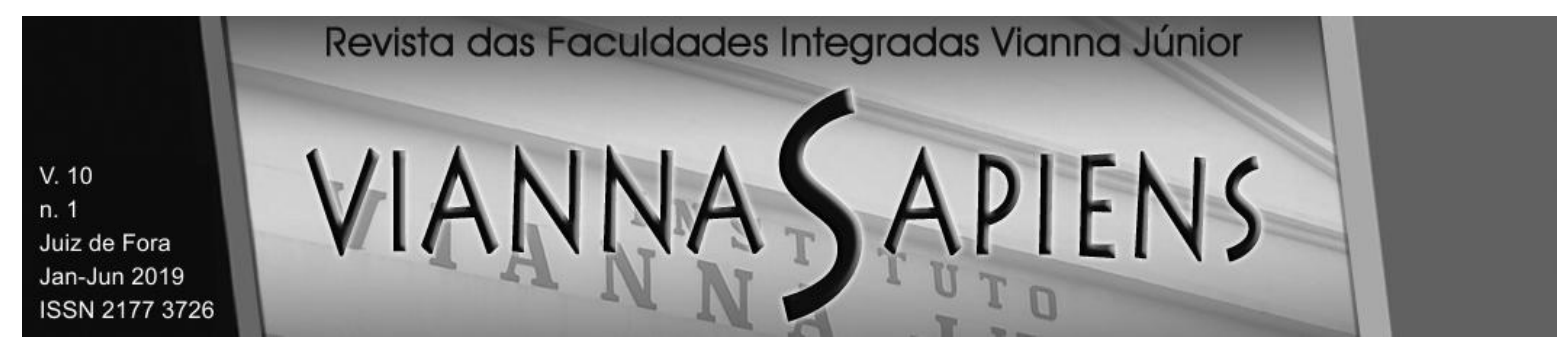

\title{
A (IM)POSSIBILIDADE DA APLICAÇÃO DE CAUTELARES ATÍPICAS NO ÂMBITO DO PROCESSO PENAL
}

DOI: 10.31994/rvs.v10i1.463

Ana Karolina Freitas Vieira ${ }^{1}$

\section{RESUMO}

O presente trabalho visa ao estudo dos princípios que regem as medidas cautelares pessoais não prisionais, a fim verificar os posicionamentos doutrinários, comuns e dissidentes, bem como o entendimento adotado pelos tribunais acerca da aplicabilidade ou não do chamado Poder Geral de Cautela no âmbito processual penal, para, ao final, concluirmos qual entendimento está em conformidade com a ordem constitucional vigente. Para tal, foi realizada pesquisa bibliográfica a partir de doutrinas brasileiras e pesquisa documental através de jurisprudências sobre o tema. Entre as conclusões obtidas por meio deste trabalho, ressalta-se que se entendeu que possibilitar a importação do instituto estudado causaria enorme insegurança jurídica para a sociedade. Isso porquanto, mostra-se minimamente perigoso deixar a critério dos magistrados a escolha da medida cautelar inominada a ser utilizada no caso concreto, apenas sob a orientação de que essa discricionariedade seja pautada no princípio da proporcionalidade.

PALAVRAS-CHAVE: PODER GERAL DE CAUTELA. MEDIDAS CAUTELARES PESSOAIS. PROCESSO PENAL. LEGALIDADE ESTRITA. INSEGURANÇA JURÍDICA.

\footnotetext{
${ }^{1}$ Autora; bacharel em Direito pelas Faculdades Integradas Vianna Junior; pós-graduanda em Advocacia Criminal pela Fundação Mineira de Educação e Cultura - FUMEC e estagiária de pósgraduação no Ministério Público de Minas Gerais. https://orcid.org/0000-0001-8524-9830.
} 


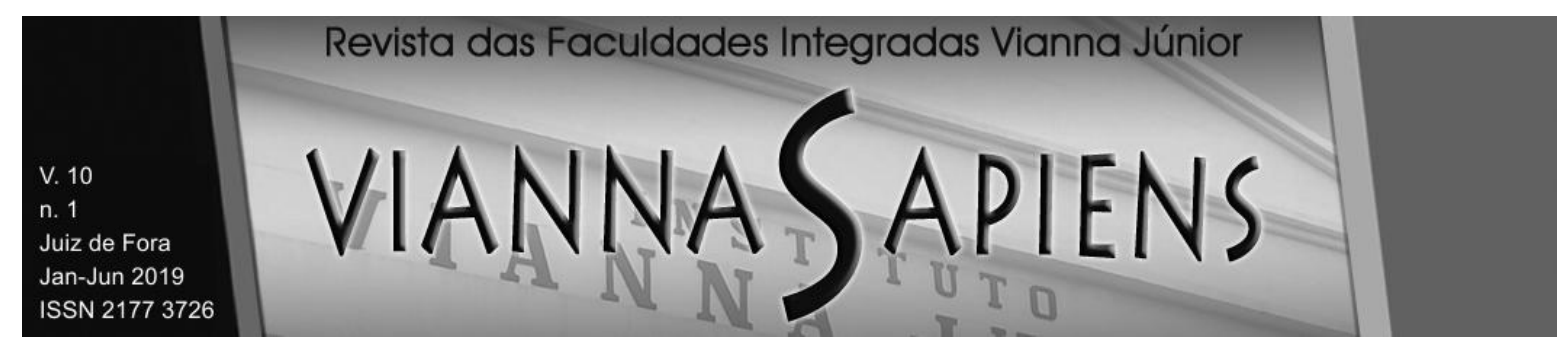

\section{ABSTRACT}

The purpose of this study is to study the principles governing non-custodial personal precautionary measures in order to verify the doctrinal, common and dissident positions, as well as the understanding adopted by the courts regarding the applicability or not of the so-called General Power of Caution in the criminal procedural framework, in order to conclude what understanding is in accordance with the current constitutional order. For this, a bibliographical research was carried out from Brazilian doctrines and documentary research through jurisprudence on the subject. Among the conclusions obtained through this work, it is emphasized that it was understood that allowing the importation of the institute studied would cause enormous legal insecurity for society. This is because it is only minimally dangerous to leave it to the discretion of magistrates to choose the unsolicited injunction to be used in this case, only on the basis that such discretion should be based on the principle of proportionality.

PALABRAS CLAVE: GENERAL POWER OF CAUTION. PERSONAL PRECAUTIONARY MEASURES. CRIMINAL PROCEEDINGS. STRICT LEGALITY. JURIDICAL INSECURITY.

\section{INTRODUÇÃO}

O Poder Geral de Cautela consiste na possibilidade de o magistrado adotar medidas cautelares não previstas em lei, a fim de se resguardar a eficácia do processo.

Não obstante a implantação das medidas acautelatórias pessoais diversas da prisão no sistema jurídico processual penal brasileiro, novidade trazida pela lei 12.403, no ano de 2011, ainda se mostra de considerável relevância o estudo desse instituto, visto que, até hoje, há quem entenda pela possibilidade de o juiz adotar medidas 


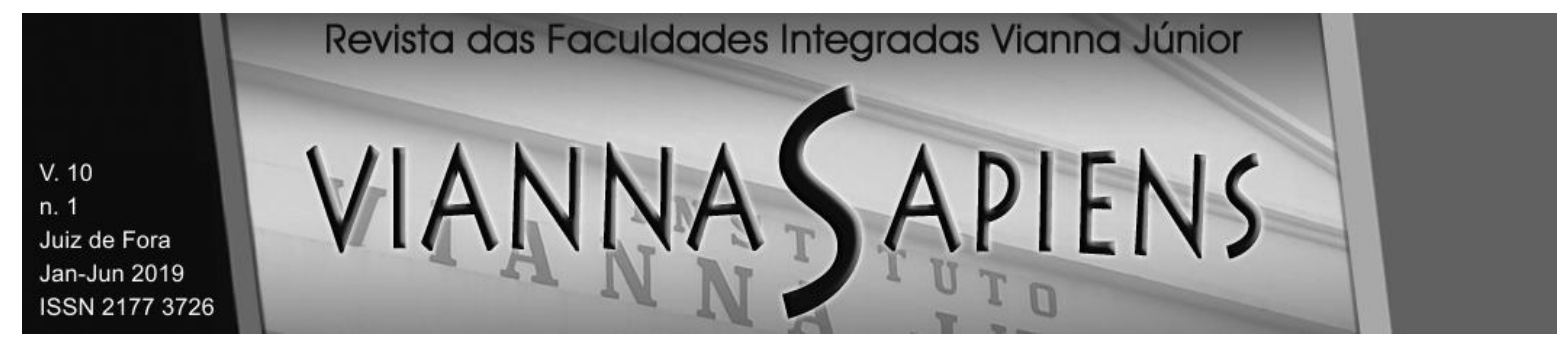

cautelares inominadas ou não previstas no rol dos artigos 319 e 320 do Código de Processo Penal (CPP).

Assim, este trabalho tem como objetivo estudar os princípios que regem as medidas cautelares pessoais não prisionais, seus pressupostos de aplicabilidade, a fim verificar os posicionamentos doutrinários, comuns e dissidentes, bem como 0 entendimento adotado pelos Tribunais acerca da aplicabilidade ou não do chamado Poder Geral de Cautela no âmbito processual penal, para, ao final, concluirmos qual entendimento está em conformidade com a ordem constitucional vigente.

Para tal, foi realizada pesquisa bibliográfica a partir de doutrinas brasileiras e pesquisa documental através de jurisprudências sobre o tema.

No primeiro tópico, far-se-á uma análise contextualizada do histórico das medidas cautelares no Brasil, tendo como marco a publicação da Lei 12.403/2011, a qual alterou o CPP, mudando de maneira significativa o sistema prisional nacional.

No decorrer do segundo tópico, por sua vez, será feita uma análise doutrinária acerca dos objetivos e requisitos de aplicabilidade das medidas acautelatórias pessoais.

No item terceiro, procura-se fazer uma análise crítica do parecer apresentado pelo então Procurador Geral da República, Rodrigo Janot, na ação de Arguição de Descumprimento de Preceito Fundamental no 395. Por fim, será feita breve explanação acerca dos entendimentos favoráveis à aplicação do instituto estudado.

\section{BREVE E CONTEXTUALIZADO HISTÓRICO DAS MEDIDAS CAUTELARES NO BRASIL}

\subsection{Inovações trazidas pela Lei $12.403 / 11$ ao sistema processual}

Em conformidade com o direito comparado, o legislador ampliou de maneira significativa o leque de discricionariedade do julgador, adicionando medidas cautelares diversas da prisão para, mediante juízo de proporcionalidade e 


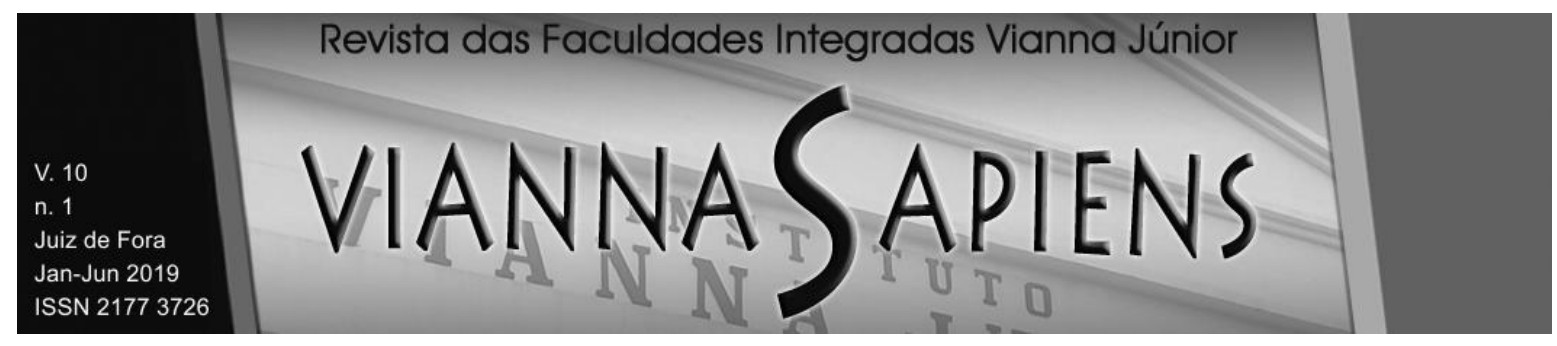

ponderação, soluções mais eficientes e eficazes fossem encontradas. Desse modo, o sistema prisional deixou de ser bipolar, relegando a carga extremista e radical e dando maiores possibilidades ao magistrado para encontrar a medida mais adequada ao caso em tratamento. Vale transcrever as lições do professor Nestor Távora (2013, p. 665) acerca do tema narrado:

Encerra-se, portanto, a angustiante dicotomia entre o cárcere e a liberdade, que eram os dois extremos existentes ao longo da persecução penal, numa verdadeira bipolaridade cautelar do sistema brasileiro. Agora, alberga-se um rol de medidas constritivas não tão extremas quanto o cárcere, nem tão brandas quanto a mera manutenção da liberdade do agente, até então condicionada ao mero comparecimento aos atos da persecução penal (antiga redação do art. 310, CPP).

A nova legislação não abarca as cautelares reais, ou seja, aquelas que visam garantir os bens patrimoniais para uma possível reparação do dano causado e para a satisfação das obrigações impostas aos condenados, a exemplo do sequestro e do arresto. Inova, contudo, apenas com relação às cautelares pessoais, relacionadas ao autor do fato e aos efeitos de seu comportamento para a ordem processual.

Conforme o disposto nos artigos 319 e 320, do Código de Processo Penal, a partir do ano de 2011, 10 (dez) medidas cautelares pessoais diversas da prisão passaram a ser previstas no ordenamento jurídico pátrio. Insta salientar que tais medidas são aplicáveis apenas pelo juiz, isto é, devem respeitar a cláusula de reserva de jurisdição, com exceção do inciso VIII - fiança - que, em alguns casos, poderá ser concedida diretamente pelo Delegado de Polícia:

Art. 319. São medidas cautelares diversas da prisão:

I - comparecimento periódico em juízo, no prazo e nas condições fixadas pelo juiz, para informar e justificar atividades;

II - proibição de acesso ou frequência a determinados lugares quando, por circunstâncias relacionadas ao fato, deva o indiciado ou acusado permanecer distante desses locais para evitar o risco de novas infrações; 


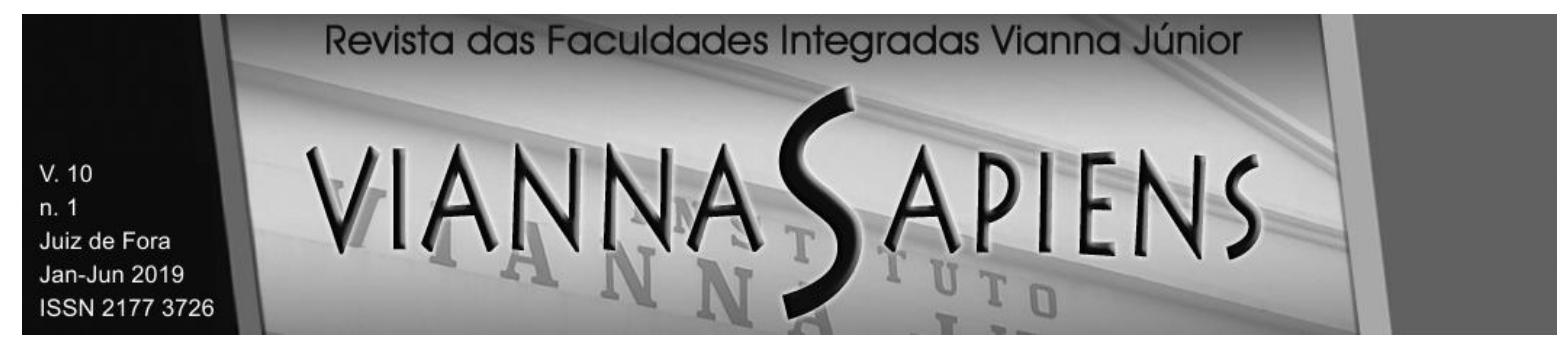

III - proibição de manter contato com pessoa determinada quando, por circunstâncias relacionadas ao fato, deva o indiciado ou acusado dela permanecer distante;

IV - proibição de ausentar-se da Comarca quando a permanência seja conveniente ou necessária para a investigação ou instrução;

$\mathrm{V}$ - recolhimento domiciliar no período noturno e nos dias de folga quando o investigado ou acusado tenha residência e trabalho fixos;

VI - suspensão do exercício de função pública ou de atividade de natureza econômica ou financeira quando houver justo receio de sua utilização para a prática de infrações penais;

VII - internação provisória do acusado nas hipóteses de crimes praticados com violência ou grave ameaça, quando os peritos concluírem ser inimputável ou semi-imputável (art. 26 do Código Penal) e houver risco de reiteração;

VIII - fiança, nas infrações que a admitem, para assegurar o comparecimento a atos do processo, evitar a obstrução do seu andamento ou em caso de resistência injustificada à ordem judicial; IX - monitoração eletrônica.

Art. 320. A proibição de ausentar-se do País será comunicada pelo juiz às autoridades encarregadas de fiscalizar as saídas do território nacional, intimando-se o indiciado ou acusado para entregar 0 passaporte, no prazo de 24 (vinte e quatro) horas (grifo nosso).

Quanto à forma de decretação das cautelares pessoais diversas da prisão, após a inovação legal, elas podem ser aplicadas como instrumento de contracautela, substituindo anterior prisão preventiva, em flagrante e temporária, ou, até mesmo, como instrumento acautelatório autônomo. Isso implica dizer que poderá também ser decretada ao acusado que estava em liberdade plena, o que não poderia ocorrer antes da vigência da lei ora analisada.

Além disso, o juiz poderá aplicá-las de maneira isolada ou cumulativa, de modo que seja escolhida a quantidade necessária a fazer cessar o risco ao regular andamento do processo, bem como a possibilidade de reiteração criminosa do investigado/acusado. 


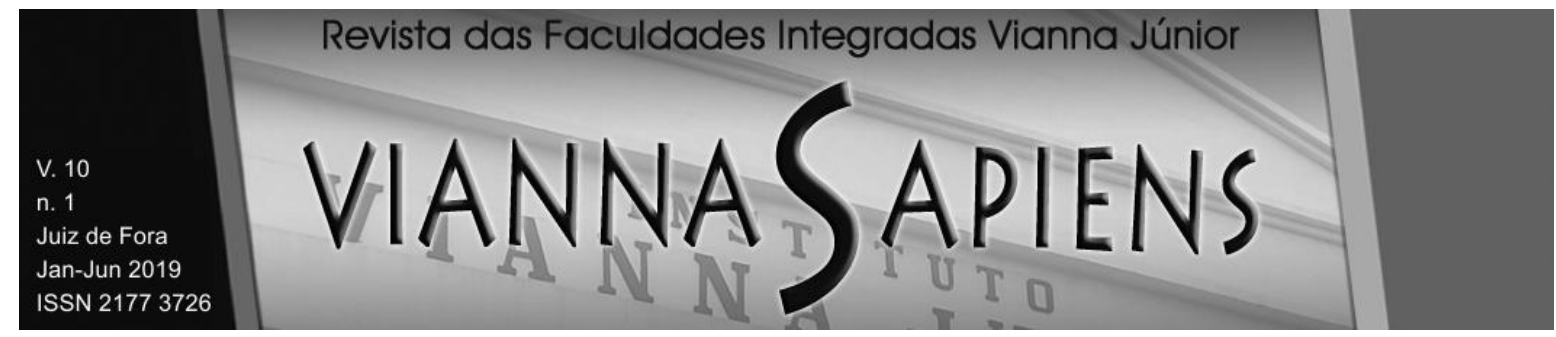

\section{OBJETIVOS E REQUISITOS DAS CAUTELARES PESSOAIS}

\subsection{Requisitos legais, aplicabilidade e finalidade das medidas acautelatórias pessoais diversas da prisão}

Primeiramente, antes que seja cogitada a decretação de qualquer medida cautelar, deve-se ter em mente que, até que haja trânsito em julgado de sentença condenatória, o investigado/acusado deve ser considerado inocente. Dessa maneira, para que se restrinja a liberdade individual, ainda que seja mediante a aplicação de uma medida cautelar diversa da prisão, alguns requisitos deverão ser seguidos para evitar excesso e banalização desse instituto.

Como enfatiza o professor Aury Lopes Junior (2016, p. 674), não há de se falar em aplicação de medidas cautelares analisando apenas o cabimento ou não da prisão processual:

Importante salientar que não se trata de usar tais medidas quando não estiverem presentes os fundamentos da prisão preventiva. Nada disso. São medidas cautelares e, portanto, exigem a presença de fumus commissi delicti e do periculum libertatis, não podendo, sem eles, serem impostas. Inclusive, se durante uma prisão preventiva desaparecer completamente o requisito e/ou fundamento, deve 0 agente ser liberado sem a imposição de qualquer medida alternativa. Em tese, alguém foi preso, por exemplo, para tutela da prova, uma vez que essa foi colhida, deverá o juiz conceder a liberdade plena, pois desapareceu o fundamento da prisão preventiva.

Em sendo assim, não pode se conceber, no sistema processual nacional, a aplicação de medidas cautelares de maneira automática, de modo que seja suficiente apenas a ocorrência de um delito para serem decretadas. Essa conclusão pode ser retirada a partir da interpretação do art. 5ํ, LVII, da Constituição Federal da República (princípio da presunção de inocência), o qual dispõe que todo acusado deve ser tratado como inocente até que se prove sua culpa definitivamente em sentença irrecorrível, bem como do art. 282, do Código de Processo Penal. Ademais, para que 


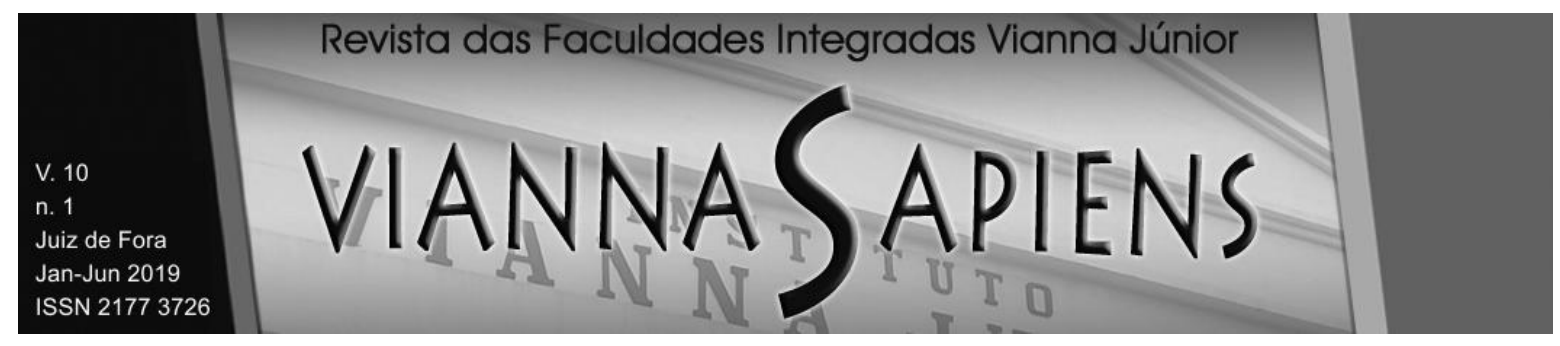

seja aplicada qualquer medida restritiva da liberdade individual, é imprescindível fundamentação por parte do magistrado:

Art. 282. As medidas cautelares previstas neste Título deverão ser aplicadas observando-se a:

I - necessidade para aplicação da lei penal, para a investigação ou a instrução criminal e, nos casos expressamente previstos, para evitar a prática de infrações penais;

II - adequação da medida à gravidade do crime, circunstâncias do fato e condições pessoais do indiciado ou acusado.

Isso posto, defende-se neste trabalho que os requisitos para a aplicação das medidas cautelares diversas da prisão são os mesmos necessários à decretação de prisão preventiva e, para a doutrina majoritária, essa é a interpretação mais acertada, muito embora o art. 282 do CPP não tenha sido expresso quanto aos pressupostos de aplicabilidade das cautelares diversas.

Seguindo essa interpretação, para que seja decretada qualquer das medidas tipificadas no artigo 319 e 320 do CPP, deve-se fazer uma análise do cabimento ou não da prisão preventiva no caso concreto, com base nos artigos 312 e 313 do CPP. Após essa análise, se a prisão não for necessária e adequada à situação, passa-se a se analisar a possibilidade de se decretar as cautelares diversas (que não deve ser decretada automaticamente, diante da falta de necessidade da prisão), bem como quais deverão ser escolhidas de acordo com a adequação e necessidade de cada caso.

Nesse sentido, professor Renato Brasileiro (2017, p. 844) consignou como objetivos das cautelares: efetivar a aplicação da lei penal diante de uma provável condenação ao final da persecução criminal; assegurar a investigação/instrução processual, de modo a coibir interferências negativas do acusado no regular andamento da investigação, o que pode vir a causar prejuízo à veracidade das provas; neutralizar o risco de reiteração criminosa, o qual é denominado "garantia da ordem pública", prevista do art. 312 do CPP. 


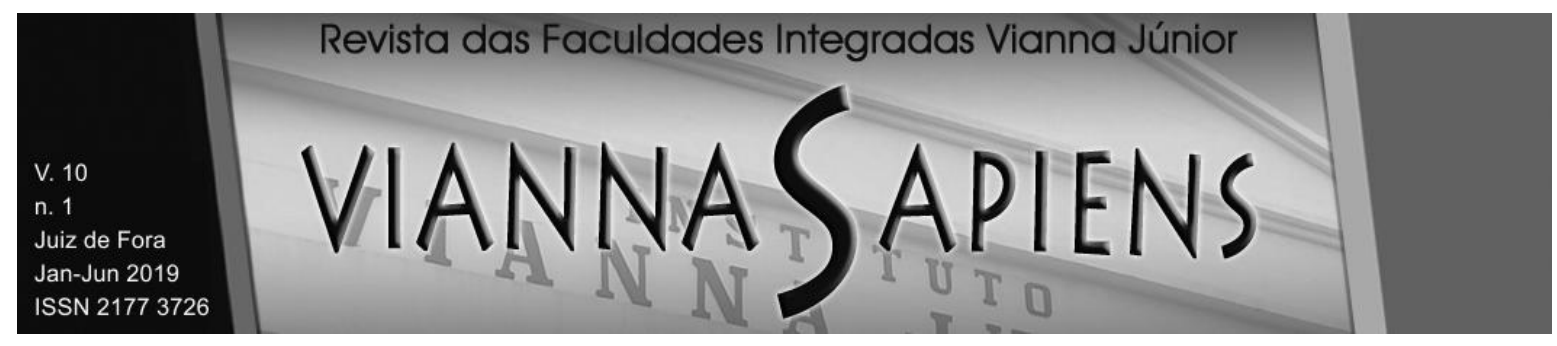

Ademais, por óbvio, a mera possibilidade de reincidir na prática delitiva pode justificar a decretação da medida cautelar em face do acusado, conforme o disposto no art. 282, inciso primeiro, in fine, CPP, desde que seja demonstrada de forma concreta nos autos, não bastando a fundamentação na gravidade em abstrato do crime imputado, nem mesmo a reprovabilidade do fato, tampouco o clamor público. Assim decidiu o STF no RHC no 79.200/BA, ainda no ano de 1999:

EMENTA: (...) III. A falta da demonstração em concreto do periculum libertatis do acusado, nem a gravidade abstrata do crime imputado, ainda que qualificado de hediondo, nem a reprovabilidade do fato, nem o consequente clamor público constituem motivos idôneos à prisão preventiva: traduzem sim mal disfarçada nostalgia da extinta prisão preventiva obrigatória. (RHC no 79200, 1a Turma, STF, Rel. Min. Sepulveda Pertence, j. 22/06/1999).

No que tange à aplicação das medidas cautelares diversas da prisão, o professor Aury Lopes Junior ensina que também devem ser respeitados os limites trazidos pelo artigo 313, CPP. Se o crime supostamente praticado tiver como sanção apenas pena de multa ou, como no caso do porte de drogas para uso próprio, advertência e prestação de serviço à comunidade, sem qualquer pena restritiva de liberdade, a doutrina prevalecente entende que nem mesmo as cautelares alternativas poderão ser decretadas nesses casos.

Deve-se respeitar o limite de pena, bem como a espécie do crime, ambos trazidos pelo inciso primeiro do artigo 313, CPP. Além disso, faz-se necessário observar se o agente é reincidente e se o crime praticado envolveu violência doméstica e familiar contra mulher, criança, adolescente, idoso, enfermo ou pessoa com deficiência.

Dessa maneira, conforme já explicitado, analisam-se, em princípio, os pressupostos de aplicação da preventiva, de modo que, se estiverem presentes os requisitos para a decretação da prisão, ainda assim deverá ser observada a necessidade e adequação da medida, a fim de que seja selecionada a cautelar mais eficiente e a que acarrete menor restrição possível à liberdade do indivíduo, nunca se 


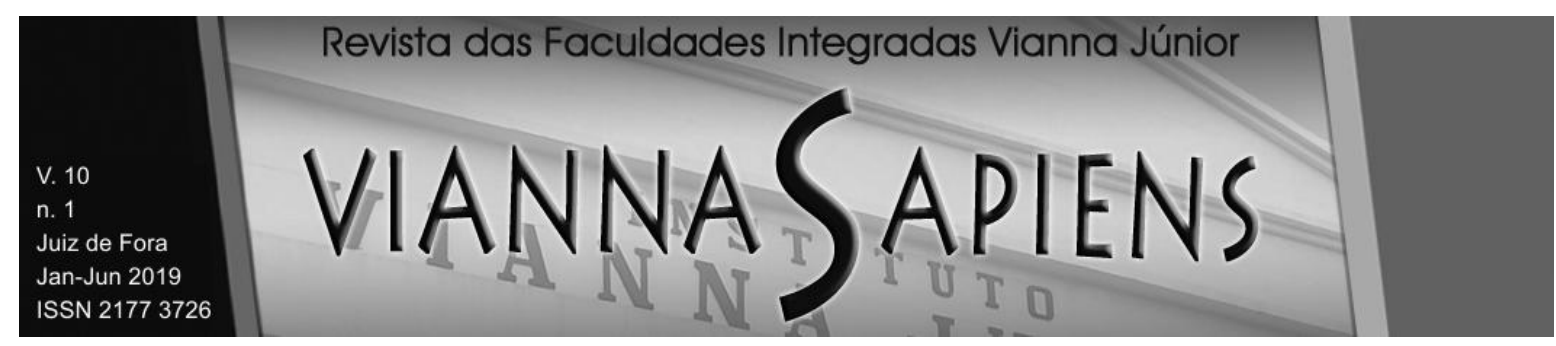

olvidando que o cárcere é excepcional, ultima ratio, como ensina o professor Aury Lopes Junior (2016, p. 674/675):

São balizas para a aplicação das medidas cautelares diversas:

- nos crimes dolosos cuja pena máxima é superior a 4 anos e exista fumus commissi delicti e periculum libertatis, poderão ser utilizadas as medidas cautelares diversas OU, se inadequadas e insuficientes, a prisão preventiva;

- nos crimes dolosos cuja pena máxima é igual ou inferior a 4 anos e exista fumus commissi delicti e periculum libertatis, somente poderá haver decretação de medida cautelar diversa;

- nos crimes dolosos cuja pena máxima é igual ou inferior a 4 anos, em que exista fumus commissi delicti e periculum libertatis, e exista uma das situações dos incisos II e III do art. 313, poderá ser decretada medida cautelar diversa ou, excepcionalmente, a prisão preventiva.

Por esse motivo, pode-se dizer que as cautelares não prisionais têm característica de substitutividade, uma vez que, embora estejam presentes os pressupostos da preventiva, deverá o magistrado, se possível, optar pela aplicação das cautelares alternativas, desde que tenham idoneidade para neutralizar o perigo de dano que se pretende evitar.

Ademais, até mesmo quando for decretar qualquer das medidas alternativas, o magistrado deve atentar-se para a excepcionalidade e a proporcionalidade visto que também restringem a liberdade individual, motivo pelo o qual não podem, de maneira alguma, ser vulgarizadas. Não é por serem medidas alternativas à prisão que as cautelares diversas poderão ser utilizadas indistintamente, como adverte 0 professor Aury Lopes Junior (2016, p. 675):

[...] eventuais medidas alternativas não podem ser banalizadas e servir para aumentar a intervenção penal de forma injustificada. Tampouco podemos desprezar a gravidade das restrições que elas impõem. Medidas como as proibições de frequentar lugares, de permanecer, e similares, implicam verdadeira pena de 'banimento', na medida que impõem ao imputado severas restrições ao seu direito de circulação e até mesmo de relacionamento social. Portanto, não são medidas de pouca gravidade. 


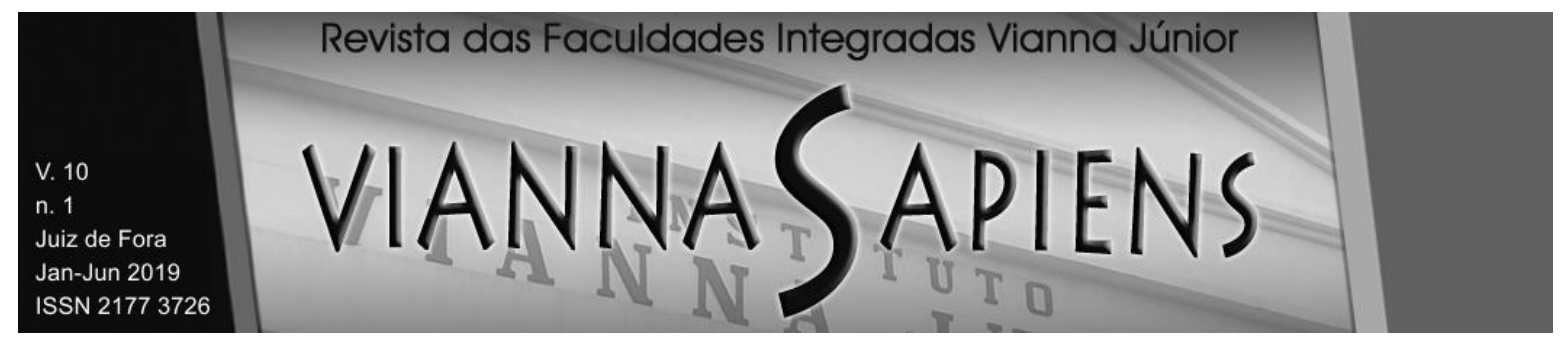

Seguindo essa lógica, diante da ocorrência de um delito culposo, há que se inferir como desnecessária a eleição de qualquer medida cautelar. Isso porquanto, o artigo 313, CPP, deixa bem claro ao dispor "nos crimes dolosos". Além do mais, por óbvio, sem a existência de vontade livre e consciente na prática do crime, também não haverá motivo para prejudicar o regular andamento do processo.

\title{
3 PODER GERAL DE CAUTELA NO PROCESSO PENAL
}

\subsection{Poder Geral de Cautela e a sua aplicabilidade no processo penal}

O Poder Geral de Cautela consiste na possibilidade de o magistrado adotar medidas cautelares não previstas em lei, considerando que é impossível o legislador antever todas as situações de risco, a fim de se resguardar a eficácia do processo. O Professor Aury Lopes Junior (2016, p. 601/602) cita Calamandrei, renomado jurista italiano, para explicar o tema:

\begin{abstract}
É reconhecido o poder geral de cautela (potere cautelare generale) confiado aos juízes, em virtude do qual eles podem, sempre, onde se manifeste a possibilidade de um dano que derive de um atraso de um procedimento principal, providenciar de modo preventivo a eliminar o perigo, utilizando a forma e o meio que considerem oportunos e apropriados ao caso. Significa dizer que o juiz cível possui amplo poder de lançar mão de medidas de cunho acautelatório, mesmo sendo atípicas as medidas, para efetivar a tutela cautelar. Tanto que no processo civil, além das medidas de antecipação da tutela, consagram um rol de medidas cautelares nominadas e a aceitação das medidas inominadas, em nome do poder geral de cautela.
\end{abstract}

É importante destacar, mais uma vez, que o Poder Geral de Cautela, ora analisado, está previsto no artigo 798, do antigo Código de Processo Civil, e agora no artigo 297, do Código Processual Civil vigente, sendo certo que o Código de Processo Penal não prevê esse instituto. Dessa maneira, trata-se de uma categoria importada do direito privado que vem sendo reconhecida também no âmbito criminal de maneira 


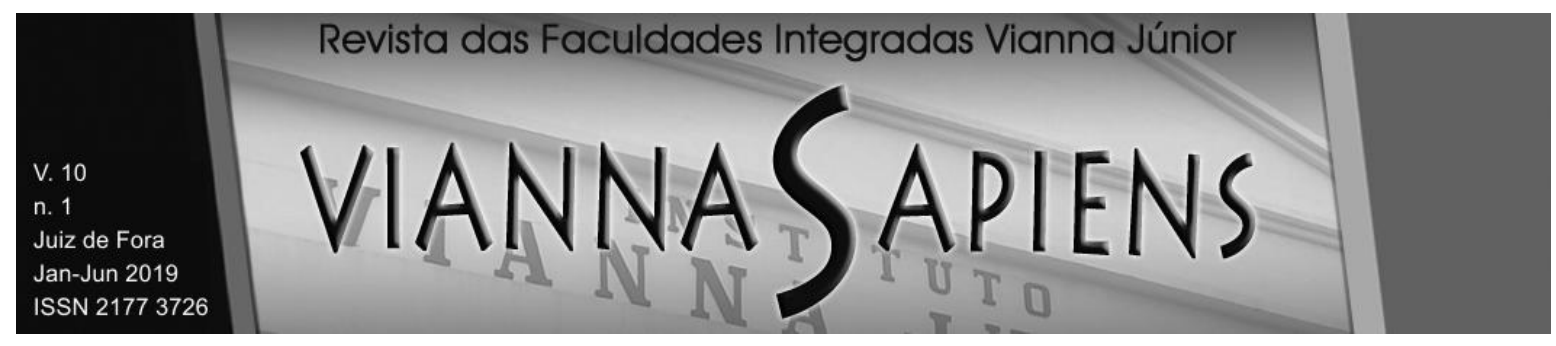

equivocada, uma vez que viola frontalmente o princípio da legalidade, bem como outros princípios que serão analisados.

Segundo o professor Aury Lopes Junior (2016), ao contrário do processo civil, em que prevalece, na maioria das vezes, interesses patrimoniais, no processo penal, a fórmula é a garantia. Assim, não há espaço para decretação de medidas atípicas, vigorando o princípio da taxatividade, uma vez que o magistrado está adstrito aos mandamentos legais.

Com isso, toda vez que houver limitação da liberdade individual, ainda que por meio da aplicação de cautelares alternativas que, em tese, são menos gravosas que o acautelamento, deverá o julgador escolher, entre as opções trazidas pela legislação ordinária, a medida mais eficiente e que acarrete menor restrição possível aos direitos fundamentais tutelados, mediante um juízo de proporcionalidade.

Deve-se observar, ainda, a adequação da medida ao caso concreto, a necessidade da decretação de pretensa medida e a proporcionalidade em sentido estrito. Por último, mas não menos importantes, devem estar presentes os demais requisitos anteriormente analisados, como sustenta o professor Alexandre Morais da Rosa (2017, p. 483):

Logo, não se pode criar, aplicar-se por analogia disposições gerais advindas de regramentos diversos, sob pena de afastar a especificidade e tornar letra morta a regra da legalidade estrita, já que se pode cautelarmente tudo, as disposições legais de nada serviram. As cautelares devem ser compreendidas como numerusclausus. Nem mais, nem menos

A discussão trazida neste trabalho, embora tenha se abrandado com a implantação das medidas acautelatórias pessoais diversas da prisão, no sistema jurídico processual penal brasileiro - inovação trazida pela lei 12.403 , no ano de 2011 -, o estudo desse instituto ainda se mostra atual e de grande relevância, visto que existem decisões atuais dos tribunais superiores admitindo a possibilidade de 0 magistrado pautar-se no Poder Geral de Cautela. Recentemente, o Procurador Geral da República apresentou um parecer na ADPF nํ395, afirmando a existência desse 


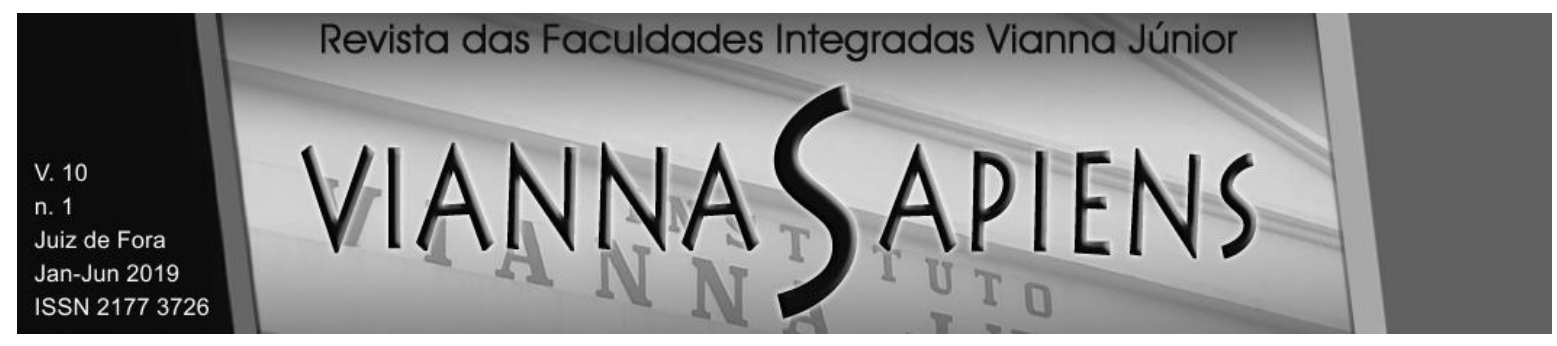

instituto também no âmbito penal. A seguir, a transcrição de parte de um julgado em sede de habeas corpus analisado pelo STF reconhece a aplicação desse instituto também na esfera criminal:

Não há como ter-se por desprovida de fundamentação ou teratológica a decisão que entende não haver elementos suficientes, demonstrados de plano, para o deferimento da liminar. Pode e deve o magistrado, ao apreciar o pedido inicial, pautar-se no poder geral de cautela para buscar outros elementos formadores das razões de decidir além daqueles trazidos pela impetração, sem que tanto caracterize constrangimento ilegal, abuso de poder ou teratologia. (STF, HABEAS CORPUS 130.140/MG, RELATOR: MIN. DIAS TOFFOLI, PUBLICAÇÃO DJE: 10/09/2015) (grifo nosso).

Vê-se claramente o equívoco do Ministro Dias Toffoli ao afirmar a existência de Poder Geral de Cautela no âmbito processual penal. Isso porque, conforme os dizeres do professor Aury Lopes Junior (2016, p. 602) “o processo penal é instrumento limitador do poder punitivo estatal, de modo que ele somente pode ser exercido e legitimado a partir do estrito respeito às regras do devido processo". Dessa maneira, não se mostra correto e nem mesmo conveniente a utilização analógica dessa categoria numa disciplina autônoma, sem qualquer similitude com o processo civil, como considera Aury Lopes Junior (2016, p. 602):

Como todas as medidas cautelares (pessoais ou patrimoniais) implicam severas restrições na esfera dos direitos fundamentais do imputado, exigem estrita observância do princípio da legalidade e da tipicidade do ato processual por consequência. Não há menor possibilidade de tolerar-se restrição de direitos fundamentais a partir de analogias, menos ainda com o processo civil, como é a construção dos tais 'poderes gerais de cautela'.

A princípio, pode parecer tentador admitir a aplicação de medidas cautelares atípicas no âmbito penal, a título de Poder Geral de Cautela, desde que seja para beneficiar o réu. Isso porquanto, pode-se entender ser mais benéfico ao acusado a aplicação de uma medida processual não prevista em lei, porém menos gravosa do que a prisão e que tenha igual eficiência do ponto de vista prático. 


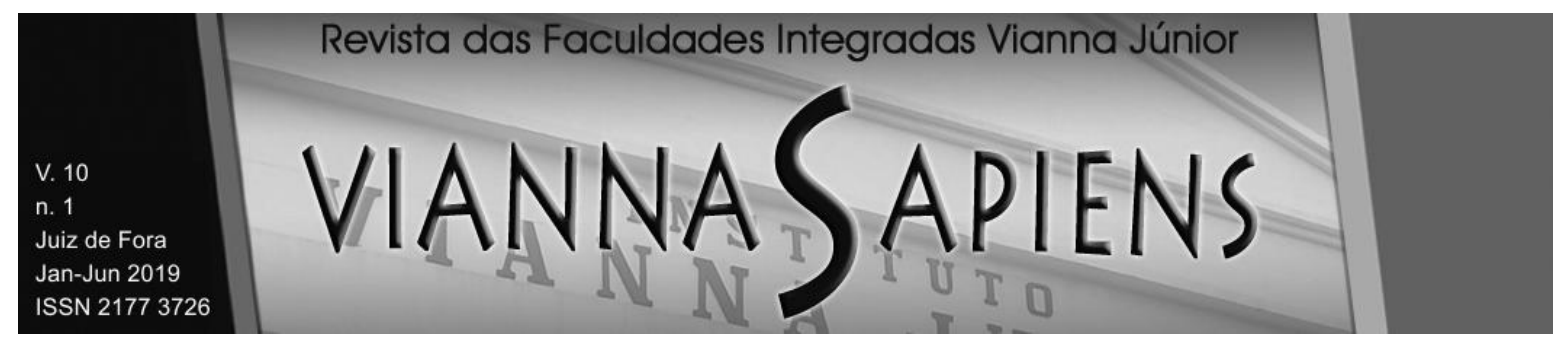

Em contrapartida, isso causaria insegurança jurídica, uma vez que ficaria a cargo do julgador usar de sua criatividade para aplicar qualquer tipo de medida que, para ele, magistrado, pode parecer menos gravosa, mas, para o acusado, pode causar profundo constrangimento, a ponto de adentrar na esfera íntima de seus direitos, afrontado sua dignidade. Um exemplo real é o caso do juiz que impôs como condição ao regime aberto que o condenado não ingerisse álcool e não frequentasse bares, boates ou locais similares (atitude comumente adotada pelos juízes de primeiro grau, porém anormal, visto que não possui qualquer fundamento na legislação).

Expressando indignação com a postura de alguns magistrados que têm dificuldade para entender os limites de sua atuação, agindo como verdadeiros ditadores togados, o professor Alexandre Morais da Rosa, juntamente com o autor Thiago M. Minagé, escreveram um artigo intitulado "Juiz pode determinar que acusado não beba e vá à igreja?", do qual segue trecho transcrito:

A nossa luta, portanto, está em dizer que em Direito Penal inexiste poder geral de cautela e, muito menos, pode-se depender da 'criatividade jurisdicional', sob pena de cometer as mais diversas atrocidades, claro, em nome do bem. Juiz não pode obrigar ninguém a nada além do previsto em lei. Se o fizer é um ditador vestido de Juiz. Não quer reconhecer seus limites.

Conforme o entendimento da doutrina majoritária, mostra-se inadmissível, no processo penal, a imposição de medidas cautelares inominadas, até mesmo sob o pretexto de estar adotando a proporcionalidade como forma de beneficiar o acusado, como entendem Luiz Flávio Gomes e Ivan Luís Marques (2011), in verbis:

O juiz da jurisdição penal não tem poderes para lançar mão de medidas atípicas ou não previstas em lei. Não existem medidas cautelares inominadas no processo penal. Todas as vezes que o juiz lança mão desse famigerado poder geral de cautela, na verdade, ele está violando o princípio da legalidade. No processo penal, forma e garantia. $O$ juiz só está autorizado a praticar os atos que contam com forma legal. Se o juiz se distancia da forma legal, resulta patente a violação à legalidade. 


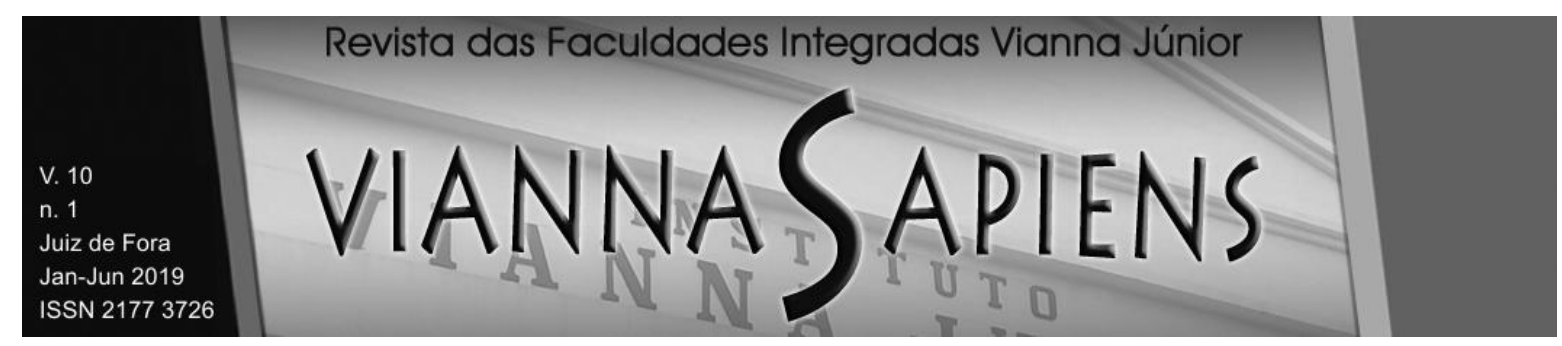

Dessa maneira, não se pode fazer interpretação analógica desse instituto/categoria previsto no processo civil, trazendo-o, assim, ao processo penal de maneira impensada. Reafirmando esse entendimento, o magistrado Rodrigo Capez (2017), em "No processo penal não existe poder geral de cautela", fez as seguintes considerações:

Em suma, as medidas limitadoras da liberdade reduzem-se um número fechado de hipóteses, 'sem espaço para aplicações analógicas ou outras intervenções (mais ou menos criativas)' do juiz, ainda que a pretexto de favorecer o imputado. Trata-se uma enumeração exaustiva (numerusclausus), e não de uma lista aberta, meramente exemplificativa (numerusapertus).

Também não concordando com a internalização do Poder Geral de Cautela na ratio processual penal, conforme excerto referenciado de seu texto publicado nas plataformas virtuais, Alexandre Morais da Rosa (2017, p. 482) defende o princípio da legalidade e taxatividade:

A liberdade do sujeito, quer na modalidade prisão, como nas medidas cautelares, demanda expressa previsão legal, bem assim demonstração argumentativa do preenchimento dos requisitos legais. Diferentemente do processo civil, no qual vigora 'o poder geral de cautela', no processo penal somente é utilizado pela invencionice do magistrado que não se deram conta do seguinte: a liberdade somente pode ser restringida nas hipóteses legais. Vigora a legalidade estrita, dado que a liberdade é a regra e não a exceção. As hipóteses de restrição da liberdade somente podem ser deferidas nos exatos termos que a Lei processual penal indica (CPP, art. 312 e 319 , dentre outras). Descabe criatividade jurisdicional. Dito de outro modo: a premissa do processo penal é a tutela da liberdade e as restrições aos direitos fundamentais devem estar previstas expressamente em lei, descabendo qualquer extensão ou criação jurisdicional.

Dessa forma, também entende o citado autor que o Poder Geral de Cautela no âmbito processual penal esbarra nos princípios da legalidade estrita e da presunção de inocência. 


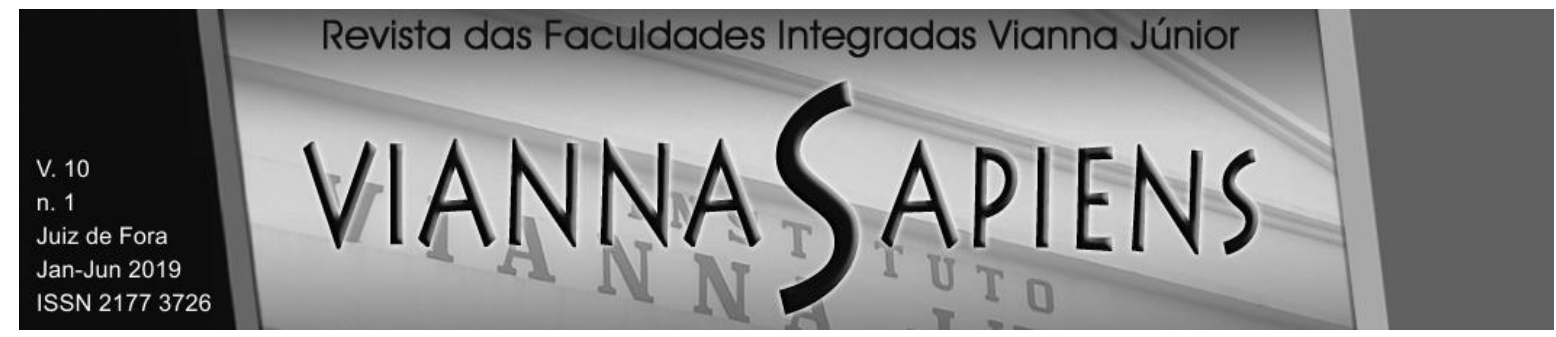

\subsection{Análise crítica ao parecer do então Procurador Geral da República citando o "Poder Geral de Cautela" no âmbito processual penal}

O Partido dos Trabalhadores propôs uma ação de Arguição de Descumprimento de Preceito Fundamental № 395, contra o artigo 260 do Código de Processo Penal, que trata da condução coercitiva para realização do interrogatório do acusado, reconhecimento pessoal e outros atos do processo penal. Isso porquanto, segundo o PT, a norma típica mencionada viola preceitos fundamentais da liberdade individual, bem como do direito de não autoincriminação.

A ADPF pretende que o Supremo Tribunal Federal declare que parte do artigo (quando dispõe sobre a condução coercitiva do acusado/investigado para o seu próprio interrogatório) não foi recepcionado pela Constituição Federal, dada a sua incompatibilidade com princípios norteadores do ordenamento jurídico brasileiro.

No parecer, Rodrigo Janot, o então Procurador Geral da República, afirma que a condução coercitiva para a prática de ato processual "decorre do poder de coação assegurado ao Estado, no exercício de suas atividades de persecução, em sentido amplo, de infrações penais", como se pode confirmar pelos seguintes trechos:

A condução coercitiva precisa ser compreendida sistemicamente como medida que decorre de forma legítima do poder geral de cautela inerente ao Judiciário, com base nos princípios orientadores da atuação jurisdicional, sem malferir a legalidade estrita. A jurisprudência do STF já admitiu expressamente utilização de poder geral de cautela no processo penal, quando permitiu que magistrado, na concessão de liberdade provisória, fixasse restrições não previstas em lei(...) Não parece haver dúvida de que condução coercitiva é medida menos gravosa do que prisão preventiva. Restrição de liberdade por curtíssimo lapso temporal, com o fito de ouvir o investigado, certamente é muito menos gravosa para a liberdade deambulatória do que a decretação de prisão temporária e menos ainda do que a preventiva. Previsão legal suficiente da medida é justamente 0 art. 260 do CPP, que autoriza condução coercitiva. (...) Não procede a tese defendida pelo requerente, de que mera condução coercitiva de pessoa suspeita, investigada ou acusada, no curso de investigação criminal, inquérito policial ou processo judicial, 


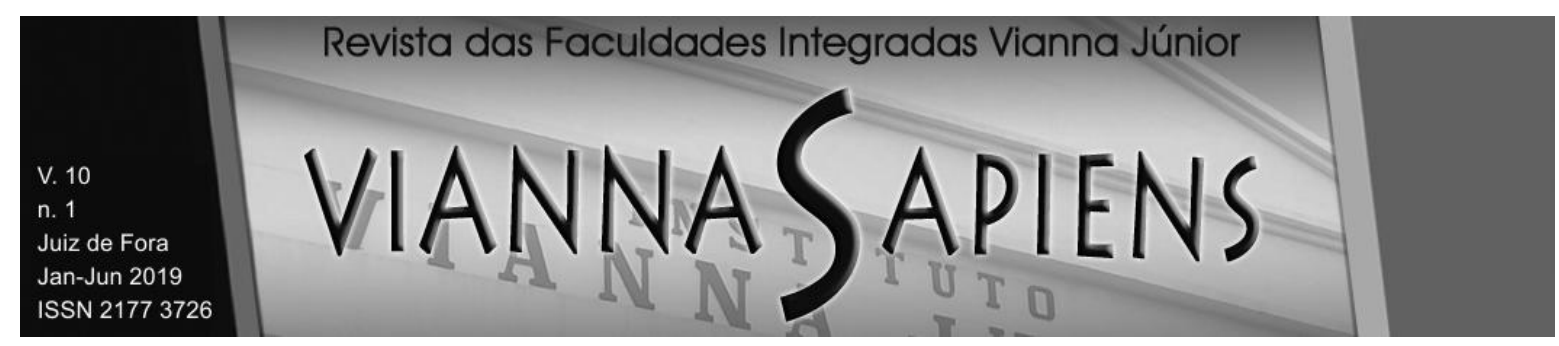

por si, afrontaria a liberdade individual e o direito a não autoincriminação (CR, art. 5ㅜ, caput e inc. LXIII, garantia conhecida pela expressão latina 'nemotenetur se detegere', isto é, ninguém pode ser obrigado a prejudicar-se) (...)Aplicação do art. 260 do Código de Processo Penal a réus e investigados somente deverá ser declarada indevida se, diante do caso, for realizada com o fim específico de obrigar o conduzido a declarar (...) Embora em situações excepcionais, a depender do caso, a condução coercitiva possa se caracterizar como verdadeira prisão quando, por exemplo, durar mais de 24 horas - na grande maioria das vezes não se equipara a encarceramento, pois restringe a liberdade por tempo reduzido (grifo nosso).

Esse é apenas um dos equívocos que pode ser cometido diante do reconhecimento, ainda que atécnico, do Poder Geral de Cautela na esfera criminal. No parecer ora analisado, percebe-se que foi utilizado esse instituto como forma de fundamentar um pensamento contrário ao que dispõe a Constituição Federal de 1998, o que causa vasta insegurança jurídica, uma vez que qualquer fundamento para aplicar medidas não previstas expressamente no art. 319 e 320 do CPP, e pior, contrária à Lei Maior, poderá resguardar-se no suposto Poder Geral de Cautela “inerente ao judiciário”, conforme afirmou a PGR no parecer transcrito.

O Partido dos Trabalhadores sustentou ser a condução coercitiva de investigado/acusado para depor em juízo ou perante autoridade policial medida contrária ao que dispõe o artigo 5ํ, LXIII, CF/88. Isso porque, nos termos do dispositivo citado, "o preso será informado de seus direitos, entre os quais o de permanecer calado". Dessa forma, o direito de não produzir provas contra si mesmo, isto é, de permanecer em silêncio diante de qualquer acusação imputada ao indivíduo, independentemente de sua natureza, consta entre os direitos fundamentais assegurados pela CR/88.

Nesse sentido é o entendimento do autor, Aury Lopes Junior (2016, fl. 578), no que concerne o comparecimento do acusado nos atos processuais:

[...] deve-se compreender, a presença do réu no processo é um direito que lhe assiste e não um dever processual (não é, portanto, carga, senão assunção de risco). Não está o juiz legitimado a praticar qualquer tipo de ato de reprovação, sendo completamente errada a decisão de "decretar a revelia" do réu ausente a instrução, como se 


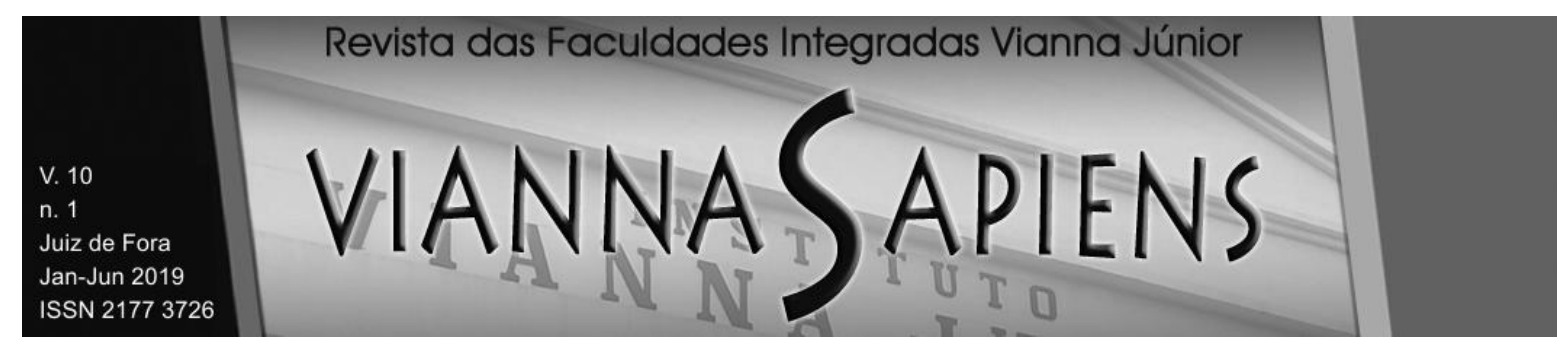

isso fosse constitutivo de um novo estado jurídico-processual ou tivesse algum efeito prejudicial ao imputado. O comparecimento ou não do réu na(s) audiência(s) de instrução é uma faculdade da defesa, atendendo aos seus interesses e estratégias probatórias, jamais uma carga processual.

Assim, não se pode conceber a coexistência do direito ao silêncio com a possibilidade de ser determinado que o imputado seja conduzido coercitivamente para prestar declarações, sendo que a faculdade de não comparecer ao seu próprio interrogatório ou, se comparecer, permanecer calado diante das perguntas que lhe forem direcionadas, são direitos previstos na constituição e também na legislação ordinária. Nesse sentido, é também o entendimento do professor Rodrigo Capez (2017):

Como se observa, a ratio da condução coercitiva é a recalcitrância do imputado, do ofendido ou da testemunha em atender ao comando da autoridade. Ocorre que, mesmo quando não configurada a prévia recalcitrância, tornou-se usual a determinação judicial de imediata condução coercitiva de investigado à repartição policial, a pretexto de momentâneo perigo à produção de provas, notadamente quando se cumprem simultaneamente outros mandados de prisão e de busca e apreensão. Invoca-se ainda, a necessidade de se evitar que os vários investigados combinem versões entre si. Essa medida não tem justificação constitucional, haja vista que o imputado tem o direito de permanecer em silêncio. Qual a razão para conduzi-lo coercitivamente para prestar depoimento, se ele goza do privilégio contra a autoincriminação?

Não faz sentido a condução coercitiva do imputado ser interpretada como uma forma de medida cautelar inominada, tendo em vista que não está prevista no rol do art. 319 e 320 do CPP, nos termos do parecer transcrito. Primeiramente, porque não está de acordo com os princípios constitucionais vigentes, dada a afronta direta aos princípios "nemotenetur se detegere", o qual está intimamente ligado ao direito ao silêncio acima mencionado e da presunção de inocência. Ainda sobre o tema, as lições de Aury Lopes Junior (2016, fl. 578): 


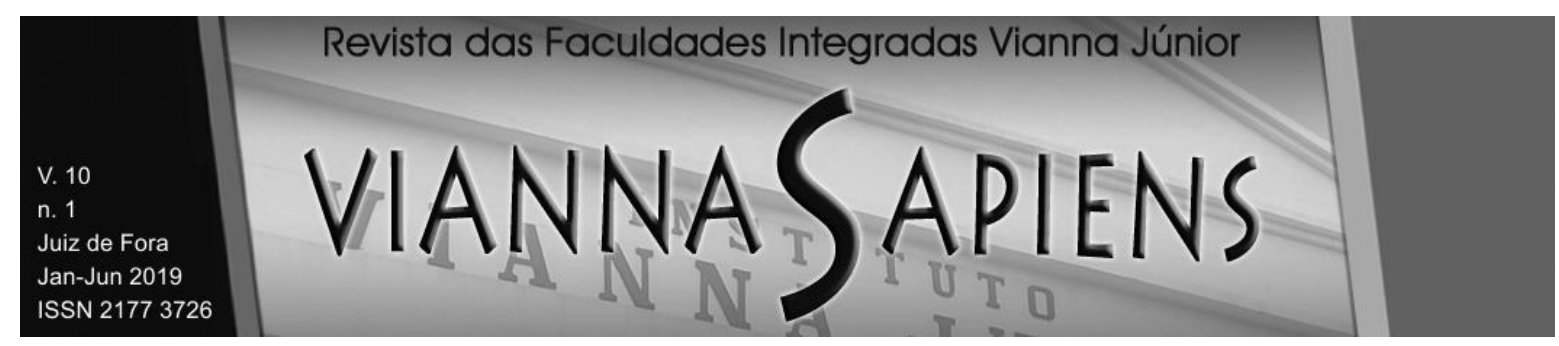

Ora, mais do que nunca, é preciso compreender que o estar presente no processo é um direito do acusado, nunca um dever. Considerando que o imputado não é objeto do processo e que não está obrigado a submeter-se a qualquer tipo de ato probatório (pois protegido pelo nemotenetur se degenere) sua presença física ou não é uma opção dele. Há que se abandonar o ranço inquisitório, em que o juiz (inquisitor) dispunha do corpo do herege, para dele extrair a verdade real... O acusado tem o direito de silêncio e de não se submeter a qualquer ato probatório, logo, está logicamente autorizado a não comparecer.

Além da Carta Magna, a Convenção Americana de Direitos Humanos - Pacto de San José da Costa Rica - também prevê que toda pessoa acusada de um delito tem o direito de não ser obrigada a depor contra si mesma, nem a confessar-se culpada. A partir de uma inferência lógica, pode-se concluir que conduzir coercitivamente o imputado equipara-se a levá-lo para prestar declarações/depor contra a sua vontade. Nessa perspectiva, o Professor Aury Lopes Junior (2016, fl. 578) continua sua análise, agora sob a verificação direta da redação do artigo 260 , CPP e afirma que, "além de completamente absurda no nível de evolução democrática alcançado, é substancialmente inconstitucional, por violar as garantias da presunção de inocência e do direito ao silêncio".

Com isso, pôde-se ter uma pequena demonstração de como seria perigoso aceitar, no âmbito do processo penal, a aplicação analógica do Poder Geral de Cautela. No parecer ora analisado, uma das afirmativas foi que "não parece haver dúvida de que condução coercitiva é medida menos gravosa do que prisão preventiva". Porém, se for adotada essa interpretação, passará a ser aceita a decretação de qualquer medida, por mais antijurídica que seja, sob o pretexto de ser menos gravosa do que a prisão - a mais gravosa medida, razão pela qual é a ultima ratio no ordenamento jurídico nacional.

Ademais, como se pode fundamentar que a condução coercitiva seria medida menos gravosa do que o cárcere quando se está diante da total ausência dos requisitos autorizadores da prisão? Dessa forma, se, no caso concreto, não seria possível a decretação da prisão temporária ou preventiva, como poderia a adoção de uma medida estranha ao rol taxativo do art. 319 e 320 do CPP ser melhor do que 


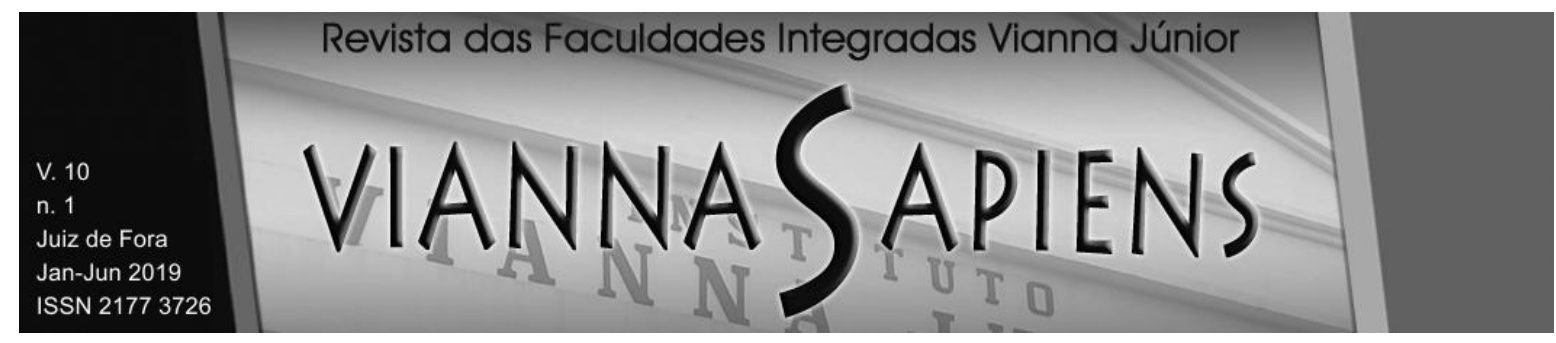

algo que, em tese, seria impossível? Nesse contexto, aduz o professor Rodrigo Capez (2017):

Dessa feita, ausentes os requisitos da custódia cautelar, não se pode impor ao investigado a condução coercitiva, ao arrepio do artigo 260 do Código de Processo Penal e do princípio da taxatividade, ao argumento de que se trataria de uma medida mais benéfica que a prisão temporária ou preventiva.

Além disso, haverá vasta possibilidade de se esvaziarem ainda mais os pressupostos de decretação das cautelares pessoais, de modo que, se, hoje, muitos magistrados fundamentam erroneamente a imposição dessas medidas, com essa possibilidade, qualquer argumento será aceito, uma vez que o juiz poderá pautar seus fundamentos unicamente no Poder Geral de Cautela inerente à sua jurisdição, como asseverado no parecer. Por conseguinte, causaria significativa insegurança jurídica a toda sociedade, que não saberá o que esperar do Estado-Juiz.

\subsection{Entendimentos favoráveis à aplicação do Poder Geral de Cautela no Processo Penal:}

Considerável maioria da doutrina processualista brasileira é radicalmente contra o reconhecimento do Poder Geral de Cautela na seara processual penal, dada a inegável afronta ao princípio da legalidade estrita, o que pode vir a causar enorme insegurança jurídica. Contudo, há quem entenda ser possível que o magistrado, ao analisar o caso concreto, escolha medidas atípicas, ou seja, não prevista dentre o rol do art. 319 e 320, CPP, desde que seja para melhorar a situação do imputado.

O professor Nestor Távora (2017, p. 1038) adota o seguinte entendimento sobre a escolha da medida cautelar pessoal mais adequada ao caso concreto:

Desse modo, embora exista um rol expresso de medidas cautelares, nada impede que o juiz estabeleça outras tantas que sejam adequadas ao caso concreto, desde que não exceda os limites 


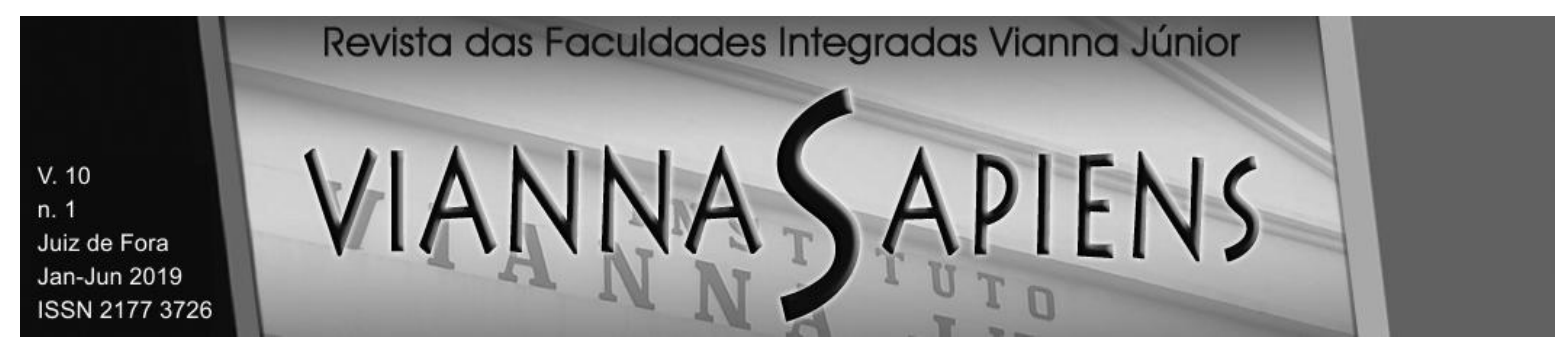

autorizados pela legislação. Daí pode o magistrado valer-se do rol do art. 319 do CPP, bem como de outras medidas menos restritivas, mas não pode aplicar medida cautelar mais gravosa sem que haja autorizativo legal expresso. Natural que seja assim, pois ninguém pode ser privado de sua liberdade ou de seus bens sem o devido processo legal, pelo que transbordaria essa limitação constitucional a adoção de medidas cautelares ou assecuratórias mais ásperas que as acolhidas legislativamente (grifo nosso).

Observa-se que, em que pese não explanar os fundamentos de sua razão de pensar, o professor citado afirma ser possível o estabelecimento de outras medidas, não previstas no rol do artigo 319 e 320, desde que adequadas ao caso concreto, de modo que não exceda os limites autorizados pela legislação (neste caso, o limite é a prisão).

Ademais, como explicitado anteriormente, o entendimento do Procurador Geral da República, Rodrigo Janot, aponta para o sentido de existir possibilidade de o juiz criminal pautar-se no Poder Geral de Cautela para fundamentar suas decisões.

Além disso, a vacilante jurisprudência do Supremo Tribunal Federal ora afirma a existência do Poder geral de Cautela no Processo penal, ora refuta essa interpretação. Da mesma forma ocorre com os demais Tribunais, que não dispõem de interpretação consolidada, oscilando com frequência no entendimento acerca do tema. In verbis, decisão do TJ-RJ reconhece a aplicação do instituto estudado no âmbito processual penal:

EMENTA: AGRAVO (LEI DE EXECUÇÃO PENAL № 7.210/84). FALTA DISCIPLINAR DE NATUREZA GRAVE (EVASÃO). REGRESSÃO CAUTELAR. ADMISSIBILIDADE PRESSUPOSTOS DA TUTELA CAUTELAR QUE SE FAZEM PRESENTES (PLAUSIBILIDADE JURÍDICA DO PEDIDO E PERIGO NA DEMORA DA PRESTAÇÃO JURIS-DICIONAL). EMBORA NÃO HAJA EXPRESSA PREVISÃO LEGAL DESSA INOMINADA MEDIDA, ELA DECORRE

DO PODER GERAL DE CAUTELA NO PROCESSO PENAL. JUÍZO DA EXECUCCÃO PENAL PODE E DEVE ESTABELECER A REGRESSÃO CAUTELAR, O QUE NÃO IMPEDIRÁ FUTURA MANIFESTAÇÃO DO APENADO (APÓS O CUMPRIMENTO DO MANDADO DE PRISÃO), SEGUINDO-SE A REFORMA OU 


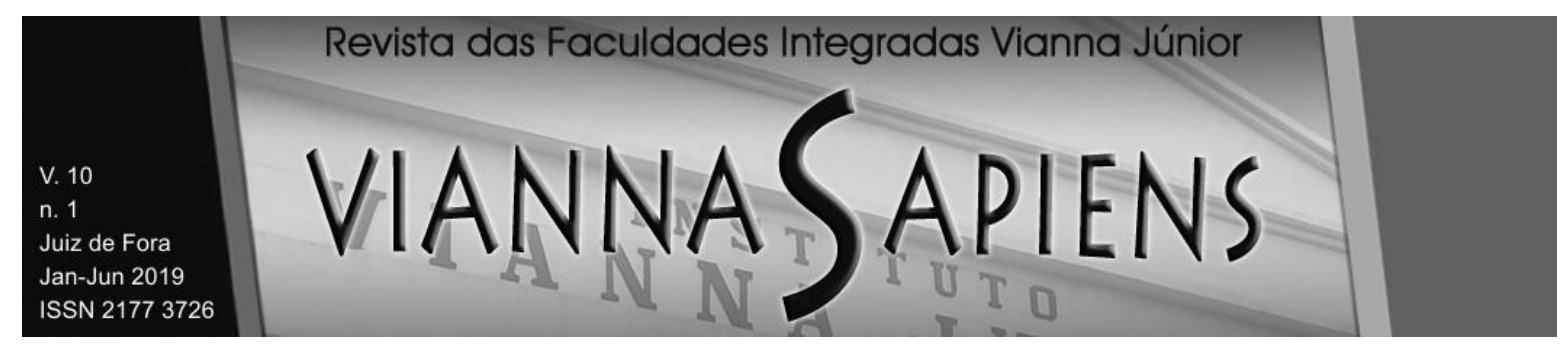

CONFIRMAÇÃO DA PROVISÓRIA DECISÃO. DESPROVIMENTO DO RECURSO DEFENSIVO. (TJ-RJ, AGRAVO EM EXECUÇÃO № 0017778-61.2012.8.19.0000, Rel. Des. Paulo de Tarso Neves, Jul.08/05/2012, Pub. 31/07/2012) (grifo nosso).

Como se observa, na decisão acima transcrita, o relator do recurso de agravo em execução, Desembargador Paulo de Tarso Neves, pautando-se no Poder Geral de Cautela, segundo ele, inerente aos juízes criminais, afirmou que é legitima a escolha de medidas cautelares não expressas em lei.

\section{CONSIDERAÇÕES FINAIS}

Este trabalho busca mostrar o significativo dilema acerca da possibilidade de se eleger, a título de poder geral de cautela, medida cautelar criminal não prevista no rol dos artigos 319 e 320 do Código de Processo Penal, mesmo diante da omissão do diploma legal citado que, em nenhum momento, referiu-se à possibilidade de o juiz criminal utilizar esse instituto.

Nesse sentido, há quem entenda que, por não haver possibilidade de antever todas as situações fáticas possíveis, o magistrado pode decretar qualquer medida cautelar ao imputado, desde que seja menos restritiva do que o cárcere. Quem se filia a essa posição, entende que o rol dos artigos mencionados é meramente exemplificativo, de modo que outras medidas, previstas ou não no códex processual penal, poderão ser eleitas, como forma de preservar a eficiência na prestação estatal.

Por outro lado, a doutrina majoritária mostra-se radicalmente contra a exportação de categorias essencialmente privadas para o direito público, uma vez que são sistemas totalmente distintos, ou seja, cada um tem suas características e peculiaridades. Dessa maneira, esses doutrinadores entendem pela impossibilidade de se reconhecer o Poder Geral de Cautela na seara processual penal, por se tratar 


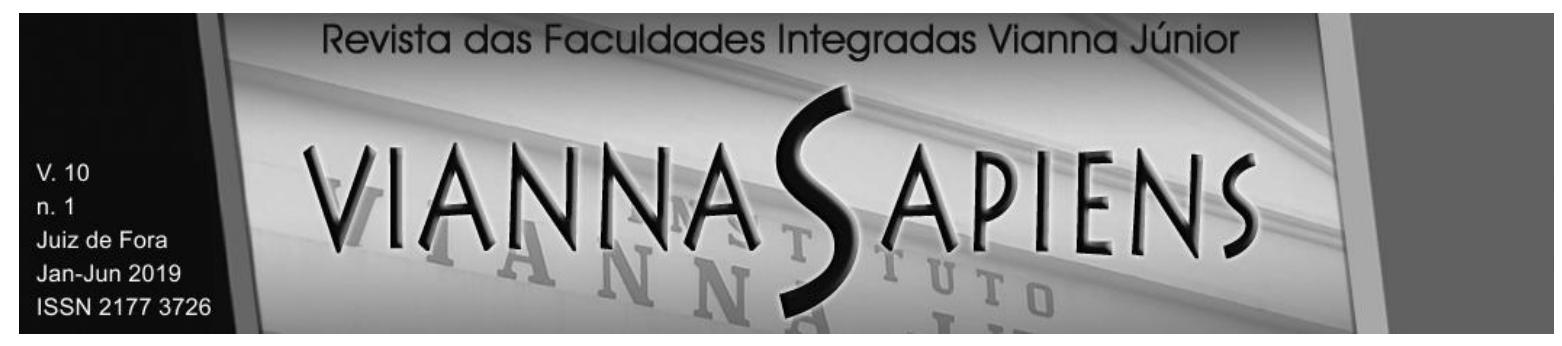

de um instituto previsto apenas no Processo Civil e contrário aos princípios previstos no Código de Processo Penal.

Além disso, segundo essa parcela da doutrina, deve-se enxergar o rol dos artigos 319 e 320, CP, que exemplifica as medidas cautelares pessoais aprisionais, como numerus clausus, ou seja, não existe possibilidade de se elegerem outras medidas, que não aquelas previstas nos artigos mencionados, sob pena de ferir o princípio da legalidade estrita, segundo o qual qualquer medida restritiva de direito deve estar expressamente prevista em lei.

Dessa maneira, considerando que, não obstante as medidas cautelares pessoais diversas da prisão sejam mais benéficas ao acusado do que o cárcere provisório, também devem ser vistas com o devido cuidado, uma vez que restringem a liberdade individual, causando mácula aos imputados que são obrigados a se submeterem a elas, muitas vezes, por longos períodos, haja vista a morosidade da justiça.

Desse modo, após ambos os posicionamentos existentes serem analisados, entende-se que possibilitar a importação do instituto estudado do direito processual civil para o processo penal causaria insegurança jurídica na sociedade. Isso porque é minimamente perigoso deixar a critério dos magistrados a escolha da medida cautelar inominada a ser utilizada no caso concreto, apenas sob a orientação de que essa discricionariedade seja pautada no princípio da proporcionalidade.

Ademais, eleger medidas inominadas a título de cautela geral não é ato consonante com os princípios constitucionais que regem o Estado Democrático de Direito, nem mesmo com os princípios processuais penais.

\section{REFERÊNCIAS}

BRASILEIRO, R. Manual de Processo Penal. 5aㅡ ed. Salvador. Editora Jus Podium, 2017. 


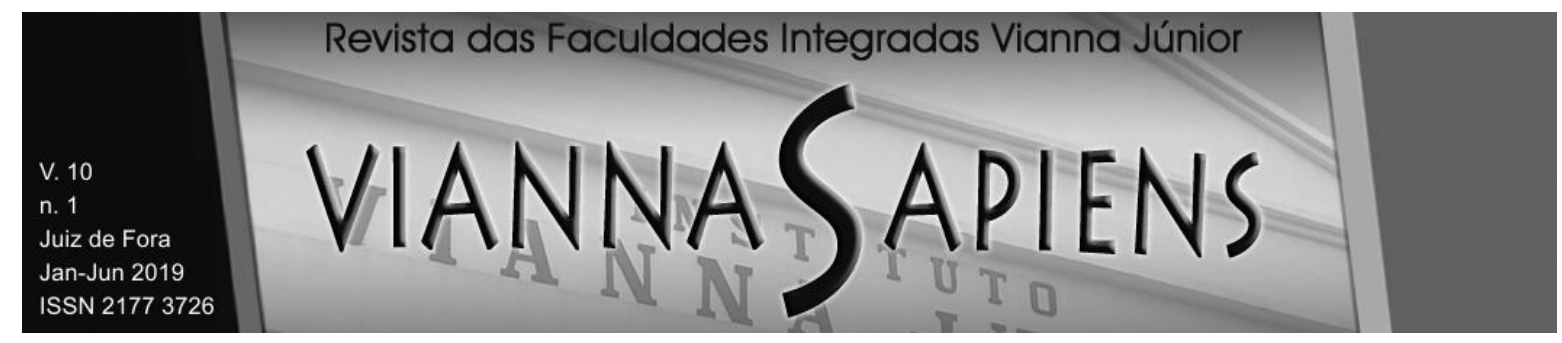

CAPEZ, R. No processo penal não existe o poder geral de cautela. 2017.

Disponível em: <http://www.fernandocapez.com.br/sala-de-imprensa/artigos/noprocesso-penal-nao-existe-o-poder-geral-de-cautela/>. Acesso em: 19/09/2017.

GOMES, L. F.; MARQUES, I. L. (Coord.). Prisão e Medidas Cautelares:

Comentários à Lei 12.403, de 4 de maio de 2011, $2^{\mathrm{a}}$ ed. São Paulo: Revistas dos Tribunais, 2011.

JANOT, R. Parecer na Arguição de Descumprimento de Preceito Fundamental no 395. 2017. Disponível em: < https://jota.info/justica/pgr-defende-no-stf-conducaocoercitiva-de-investigado-07022017>. Acesso em: 19/09/2017.

LOPES JUNIOR, A. Direito Processual Penal. 13 ed. São Paulo: Saraiva, 2016.

NEVES, P. de N. Ementa: Agravo (lei de execução penal no 7.210/84). Falta disciplinar de natureza grave (evasão)... 2012. Disponível em: <https://tjrj.jusbrasil.com.br/jurisprudencia/115113591/agravo-de-execucao-penal-ep177786120128190000-rj-0017778-6120128190000 >. Acesso em: 19/09/2017.

PERTENCE, S. Ementa: Prisão por pronúncia... 1999. Disponível em < https://stf.jusbrasil.com.br/jurisprudencia/739115/recurso-em-habeas-corpus-rhc79200-ba>. Acesso: 19/09/2017.

ROSA, A. M. da. Guia do Processo Penal conforme a Teoria dos Jogos. $4^{\mathrm{a}}$ ed. Florianópolis: Empório do Direito, 2017.

ROSA, A. M. da; MINAGÉ, T. M. Juiz pode determinar que acusado não beba e vá à igreja? 2016. Disponível em:

<http://justificando.cartacapital.com.br/2014/10/18/juiz-pode-determinar-queacusado-nao-beba-e-va-igreja/>. Acesso em: 31/07/2017.

TÁVORA, N. ANTONNI, R. Curso de Direito Processual Penal. $8^{\text {a }}$ ed. Salvador: Editora Jus Podium, 2013. 


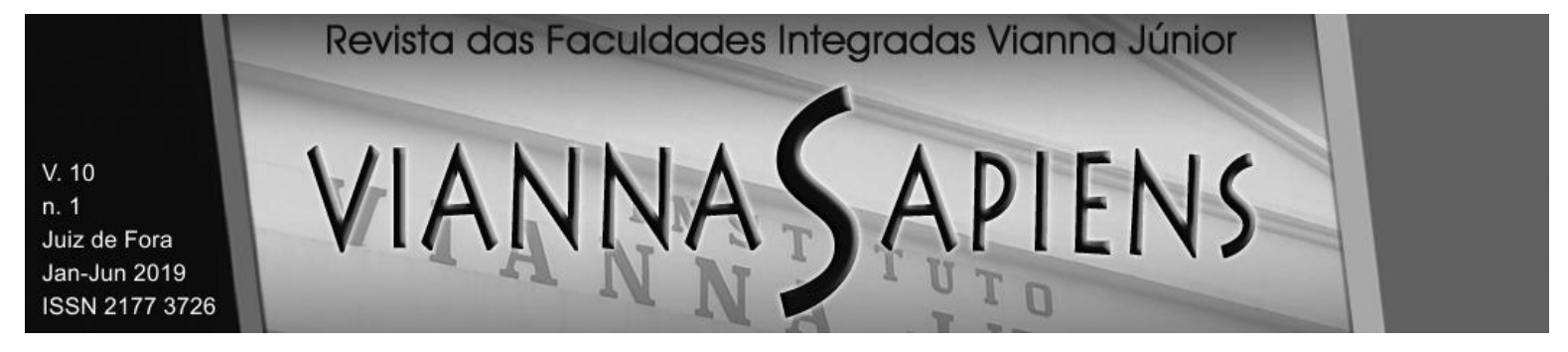

TOFFOLI, D. Ementa: Vistos. Habeas Corpus, com pedido de liminar, impetrado... 2015. Disponível em:

<http://stf.jus.br/portal/jurisprudencia/visualizarEmenta.asp?s1=000221167\&base=ba seMonocraticas $>$. Acesso em: 19/09/2017.

Recebido em 20/11/2018

Publicado em 12/07/2019 